Jurnal Keperawatan Padjadjaran

ISSN 2338-5324 (print)

ISSN 2442-7276 (online)

Online di http://jkp.fkep.unpad.ac.id

DOI : $10.24198 / \mathrm{jkp}$

\title{
Comparison of Four-Level Modification Triage with Five Level Emergency Severity Index (ESI) Triage Based on Level of Accuracy and Time Triase
}

\author{
Zustantria Agustin Minggawati ${ }^{1}$, Achmad Faried ${ }^{2}$, Ayu Prawesti Priambodo ${ }^{3}$ \\ ${ }^{1}$ Poltekkes TNI AU Cibabat, Cimahi, Indonesia \\ ${ }^{2}$ Faculty of Medicine Universitas Padjadjaran, Bandung, Indonesia \\ ${ }^{3}$ Faculty of Nursing Universitas Padjadjaran, Bandung, Indonesia \\ Corresponding email: minggawati87@gmail.com
}

Submitted: 06-07-2019 Accepted: 01-04-20 Published: 08-04-2020

\begin{abstract}
The triage system currently recommended by the Association of Emergency Physicians (ACEP) and Emergency Nurses Association (ENA) is a five levels triage, Emergency Severity Index (ESI) due to more structured, concise, and clear. Cibabat Hospital used a relatively new triage of four modified levels of the Australian Triage Scale (ATS) which accuracy and time triage have not been evaluated. The purpose of this study was to compare the four level triage of modification of ATS and five levels of ESI triage based on accuracy and time triage. The researcher used a quantitative quasi-experimental design with samples of triage activities totaling 38 in the control group and 38 intervention groups, using accidental sampling techniques. Univariate analysis consisted of frequency distribution for nurse characteristics, time triage and accuracy, bivariate analysis used the Mann-Whitney test. The results showed there were no differences, triage modification of ATS with ESI triage in accuracy (p-0.488), and length of triage (p-0.488) ESI triage accuracy was in the expected triage category $(76.3 \%)$, under triage $(13.2 \%)$, and over triage $(10.5 \%)$. Triage modified ATS, expected triage $(73.7 \%)$, under triage $(18.4 \%)$, and over triage $(7.9 \%)$. ESI triage has more expected and less under triage than ATS modification triage. Under triage caused prolong waiting times, unexpected risks, increases morbidity and mortality. Based on the length of time, ESI triage averaged 167 seconds, triage modification of ATS an average of 183 seconds. ESI flowchrat is easier to understand because is simple, has slight indicators in each category. Conclusion of this study is there is no significant difference in the level of accuracy and duration of triage. However, based on data distribution, ESI triage gives more expected triage decisions, less under triage and 16 seconds faster. Suggestions given to the Cibabat Hospital, can use ESI triage as an alternative triage assessment option because easy to use, structured, simple, and clear.
\end{abstract}

Keywords: Accuracy, Australian Triage Scale (ATS), Emergency Severity Index (ESI) Time Triage, triage. 


\section{Introduction}

Emergency department (ED) is one of the most vital service units in saving the lives of patients who get emergencies situation. Nurses are health workers with the biggest and holding presentation an important role in service delivery health. Nurse in ED often exposed to various sources of danger can threaten his life and health. Nurses can also get an accidents due to having to provide fast and accurate when they do triage assessment (Ramdan \& Rahman, 2017). Triage is an important component of ED in the management of these emergency patients. Triage is defined as the process of evaluating patients to prioritize administration of care based on the urgency of existing clinical conditions (FitzGerald, Jelinek, Scott, \& Gerdtz, 2009). Accuracy in determining triage criteria can improve the flow of patients who come to the emergency department, maintain unit resources so that they can focus on handling truly critical cases, and transfer non-emergency cases to appropriate health facilities. Triage decisions will place patients on a triage scale. Three types of decision of triage are expected triage, over triage, and under triage. Inappropriate triage decisions will threaten patient safety, increase mortality and morbidity inappropriate use of resources. Patients with over triage make the patient in the room that is not right and under triage makes the patient seriously wait longer (Considine, Ung, \& Thomas, 2001). Wait longer made length of stay in Emergency departement increase. Lengthening the period of hospitalization will also add to the activities and workload of nurses (Nurmansyah, Susilaningsih, \& Setiawan, 2014; Ardiyani, 2015). Although the workload does not have an impact on job satisfaction, it must still be adjusted the workload in order to improve service quality to the patients (Safdar, Susilaningsih, \& Kurniawan, 2019).

Another important thing in triage is time triage. Time is considered an important tool for measuring the quality of services at the ED (Bukhari et al., 2014). According to Khankeh, Zavareh, Naghdloo, Hoseini, and Rahgozar in 2013 stated that triage can significantly reduce the waiting time interval for patients entering the ED to receive treatment services and increase patient satisfaction. Another study conducted by Levsky, Young, Masullo, Miller, and Herold in 2008 reinforced the results of the Khankeh study, which explained that the implementation of the use of triage and treatment programs in community hospitals was closely related to reducing patient waiting time. The duration of triage is the time used by nurses in conducting triage studies.

The triage system used by emergency departments in world has many variety. Starting from two levels, three levels, four levels up to five levels triage. The triage system that is currently being developed is a five-level triage. Some triage five levels are Emergency Severity Index (ESI), Canadian Triage Acuity Scale (CTAS), Manchester Triage Scale (MTS), and Australian Triage Scale (ATS) (Gilboy, Tanabe, Travers, \& Rosenau, 2011). ESI is the most superior triage than the others. ESI is easier to use, reduces subjectivity in determining triage decisions, more accurate, can predict resources who needed by patients and has a good of validity and reliability (ElshoveBolk, Mencl, Rijswijck, Simons, \& Vugt, 2007; Christ, Grossmann, Winter, Bingisser, \& Platz, 2010; Mace \& Mayer, 2008; Golzari, Soleimanpour, Raoufi, Salarilak, Sabahi, Nouri, \& Heshmat, 2014).

The triage system in Indonesia has not been standardized so that its use in various regions varies greatly. In several major hospitals in Indonesia which adopted the ATS triage, Cipto Mangunkusumo Hospital in Jakarta used ATS modification which shortened to 3 levels. Karyadi Semarang Hospital also modifies ATS to 3 levels based on color categories (red, yellow, and green). Hasan Sadikin Hospital Bandung modifies ATS into 3 categories, mild, moderate, and severe. The same thing was done by Cibabat Hospital which adopted ATS but they shortened into 4 levels.

The application of this triage system is still relatively new because it was first used at the end of November 2016, where previously there was only a primary and secondary triage at emegency departemen in Cibabat Hospital, so it was not known what patients were included in the emergency category. This caused a classification error where the patient 
who is in the false emergency enters a true emergency patient. According to the Cibabat Hospital annual report data in 2015 it was found that false emergencies were $54 \%$ while true emergencies were only 46\% (RSUD Cibabat Cimahi, 2015). So, its needed to decrease the number of false emergencies by using new triage which reduces subjectivity in determining triage decisions. ESI is of choices system triage which easy to use and more accurate.

\section{Method}

The design of this study is quantitative research with a quasi experimental approach. This researched setting in Emergency Unit Cibabat Hospital. The Data was collected in Oktober 2017. Sample of this research was 38 triage activity from 15 nurses who accepted to join in this study. It used comparatif numeric unpaired with $\mathrm{Z} \alpha=1.96$ and $\mathrm{Z} \beta=1.28$ (Dahlan, 2013). There were two groups, the control group was patients with assessment used four levels of ATS modification triage while the intervention group was used the five-level ESI triage method. The study sample was a triage activity of 38 triage studies conducted by 15 nurses. The research instrument used the observation format of level accuracy and time triage of ATS modification triage and ESI triage format. Univariate analysis consisted of frequency distribution for nurse characteristics, time triage and accuracy, bivariate analysis used the Mann-Whitney test. ESI has a good validity 0,68 (Christ, Grossmann, Winter, Bingisser, \& Platz, 2010). This study was approved by the ethics committee of medical faculty of Padjadjaran University in October 2017. Informed consent was given to triage nurses regarding the title, purposes, and advantages of the study.

The level of accuracy was done by collected data twice. First, the nurses used a triage of four levels of ATS modification in 38 patients. Second, the same nurses carried out triage used five levels of ESI triage and triage four levels of ATS modification in 38 other patients. Each triage assessment conducted by nurses is also accompanied by an assessment by Gold Standard. All result by nurses compared with result from Gold Standar. There were three results of accuracy triage, Over triage, Expected triage, and Under triage. In time triage, a triage assessment by nurses was conducted twice

Table 1 Level of Accuracy of the Triage Method Four Levels of ATS Modification and Five-Level ESI Triase Method

\begin{tabular}{lccccccc}
\hline \multirow{2}{*}{ Triage } & \multicolumn{2}{c}{ Expected Triage } & \multicolumn{2}{c}{ Over Triage } & \multicolumn{2}{c}{ Under Triage } & \multirow{2}{*}{$(\mathbf{\%})$} \\
\cline { 2 - 7 } & $\mathbf{( f )}$ & $\mathbf{( \% )}$ & $\mathbf{( f )}$ & $\mathbf{( \% )}$ & $\mathbf{( f )}$ & $\mathbf{( \% )}$ & \\
\hline ATS modification & 28 & 73.7 & 3 & 7.9 & 7 & 18.4 & 100 \\
ESI & 29 & 76.3 & 5 & 10.5 & 4 & 13.2 & 100 \\
\hline
\end{tabular}

Table 2 Mann-Whitney Test Difference Test Accuracy Levels

\begin{tabular}{lccccc}
\hline \multicolumn{1}{c}{ Triage } & $\mathbf{n}$ & Mean Rank & Sum of Ranks & Z & p-value \\
\hline ATS modification & 38 & 37.17 & 1412.50 & -693 & 0.488 \\
ESI & 38 & 39.83 & 1513.50 & & \\
\hline
\end{tabular}

Table 3 Time Triage Overview using the Four Levels of ATS Modification and Five-Level ESI Triage Method

\begin{tabular}{lcccccc}
\hline \multicolumn{1}{c}{ Triage } & $\mathbf{n}$ & Mean & Categories & Std Deviation & Min & Max \\
\hline ATS modification & 38 & $\begin{array}{c}183 \text { seconds (3 } \\
\text { minute 3 seconds) }\end{array}$ & standard & 54.22909 & 75.00 & 290.00 \\
ESI & 38 & $\begin{array}{c}167 \text { seconds (2 } \\
\text { minute 47 seconds) }\end{array}$ & standard & 48.48889 & 72.00 & 260.00 \\
\hline
\end{tabular}


Zustantria Agustin Minggawati: Comparison of Four-Level Modification Triage with Five Level ESI

Table 4 Time Triage Test Mann-Whitney Test

\begin{tabular}{lccccc}
\hline \multicolumn{1}{c}{ Triase } & $\mathbf{n}$ & Mean rank & Sum of Ranks & Z & P-value \\
\hline Teriase modifikasi ATS & 38 & 41.54 & 1578.50 & -1.200 & 0.230 \\
Triase ESI & 38 & 35.46 & 1347.50 & & \\
\hline
\end{tabular}

used triage four levels of modification of ATS and triage of five levels of ESI in the same patient. The two triage system was compared how long it would taken.

\section{Results}

Based on the table above it is known that ESI triage compared to the triage of four ATS modification levels is given more expected than overtriage and undertriage categories.

Based on table 2 above it is known that the value of $p$-value $>$ alpha or $0.488>0.05$ it showed that the accuracy of triage four levels of ATS modification used by the Cibabat Hospital with ESI triage is not significantly different.

Based on table 4 , it is known that the average time triage used four modification levels of ATS is 183 seconds or 3 minutes 3 seconds. In triage of five ESI levels the average time triage was 167 seconds or 2 minutes 47 seconds. So, ESI faster than ATS modification.

Based on table 4 above, it is known that the value of $p$-value $>$ alpha is $0.230>0.05$ thus the time triage used four levels of ATS modification with ESI triage duration is not significantly different.

\section{Discussion}

Based on the results of the study, it is known that there was no significant difference indicated by the use of four levels of ATS modification triage with five levels of ESI triage both in terms of accuracy and length of triage. Statistically, the two results showed there is no difference, but from the distribution of data there is a difference 16 seconds from the two triages where the ESI average is 16 seconds faster than four ATS modification triage. ESI triage on average takes 2 minutes 27 seconds while triage four modification levels of ATS for 3 minutes 3 seconds. The fastest time needed for ESI in
72 seconds and the longest takes 4 minutes 20 seconds. In triage four modification levels of ATS the fastest time used is 75 seconds and a maximum of 4 minutes 50 seconds. The fastest time difference is only 3 seconds and the longest difference is 30 seconds. From the minimum and maximum time in both triages there is a considerable distance. This is due to the variety of cases of patients with different severity.

Based on the difference in time in the triage period above, it is known that the use of ESI triage is faster than the triage of four levels of ATS modification. Although only slightly different, we must know that triage time is an important element of triage use. When it becomes one of the important factors in making the right decision for triage, the information needed must be collected quickly and decision-making must be done on time (Dadashzadeh, Abdolahzadeh, Rahmani, \& Ghojazadeh, 2013).

If we faster to take triage time, so the patient will be soon transferred from triage room to emergency room. The use of shorter triage will reduce patient waiting time for treatment and this will increase patient satisfaction during the ED (Khankeh, Zavareh, Naghdloo, Hoseini, \& Rahgozar, 2007). According to Villa, Weber, Polevoi, Fee, Maruoka, and Quon in 2018, based on the results of their research, it is known that the reduction in the length of triage can be done by implementing ESI triage in the ED. The reduction in time was mainly due to nurse intervention focused only on the questions posed by ESI without being accompanied by patient administrative data. The fast triage time will have a positive impact on the quality of care in the hospital emergency departement. Besides being fast, ESI triage also has other advantages, including simple, easy to understand, and easy to apply. According to Elshove-Bolk, Mencl, Rijswijck, Simons, and Vugt in 2007, the nurses stated that ESI was easier to use, reduced subjectivity in determining triage decisions and was more accurate than other 
triage systems. This was also confirmed by statements from several emergency nurses in Cibabat Hospital using ESI triage. They stated that ESI was very simple, there were not many indicator points or signs and symptoms in each category, the flow of sorting was also easy to understand. But sometimes it is rather confused when determining the resources according to patient needs.

As we know the philosophy of triage prioritizes are accuracy, and fast. When viewed from accuracy, both triage four levels of modification of ATS and ESI triage were not significantly different. This shows that both triages are equally accurate to use. But we need to examine it more deeply based on the results of triage decisions that are obtained whether over trage, ecpexted triage, and under triage. These three decisions provide a clearer picture of the results of the accuracy of the triage assessment. In under triage and expected triage categories, ESI triage is better than the triage of four ATS modification levels.

Over triage is the result of a triage assessment decision where the patient receives a triage code that is higher than the actual level of urgency. Over triage in ESI triage is $10.5 \%$ while in triage four modification levels are $7.9 \%$. There was a difference of $3.4 \%$ between the two triages where ESI triage has a good contributed than the triage of four ATS modification levels. Overtriage decisions can result in short waiting times for medical intervention. However, it will have a negative impact on other patients who are waiting at the ED because they have waiting time longer. Significantly, the overtriage decision does not have consequences for the patients, instead patients will benefit from being given action first by health worker compared to other patients who are at the lower levels. Overtriage does not have a direct effect, but an Overtriage can interfere with the provision of health services and provide risks to other patients (Ekin \& Mophet, 2015; Hinson et al., 2018).

Expected triage is the result of a triage assessment according to a triage decision where the patient receives a triage code that suitabel with level of urgency of the patient. The expected triage decision on ESI triage is 76.3 while the triage of four ATS modification levels is 73.7 with a difference of both at $3.4 \%$. This shows that ESI triage gives more appropriate triage decisions compared to triage four levels of ATS modification. This decision can optimize the time for patient medical intervention and reduce adverse risks. This decision is expected to be carried out by triage nurses while carrying out their duties. The right decision will provide the right rescue action.

In under triage category, ESI triage was a smaller percentage of $13.2 \%$ compared to triage four ATS modification rates of $18.4 \%$ so that the difference obtained was $5.2 \%$. Under triage is the result of a triage decision where the patient receives a lower triage code than the actual one. This decision has the potential to produce prolonged waiting times for medical intervention and risk of poor outcomes. Under triage is a medical error that can increase the number of mordibitas and mortility. Patients who are supposed to get treatment first are not prioritized so that the patient's life cannot be immediately give treatment. Under triage also directly impacts patient safety due to long waiting times (Ekin \& Mophet, 2015). Patients will be more need a long time to get the medical treatment. Of course this will greatly endanger the lives of patients, especially if the patient's level of emergency is in level one. Because the triage nurse provides a level below the patient does not receive priority treatment by health workers.

Accurate and fast triage decisions have a significant impact on patient management. Accuracy triage decision making is the based for determining priorities to provide emergency care so that it has a positive impact on patient care outcomes (Dadashzadeh, Abdolahzadeh, Rahmani, \& Ghojazadeh, 2013). The accuracy of the use of triage can not be separated from the ability to decide the patient's emergency. According to Smith and Cone 2010, triage decision making is based on critical thinking, intuition, and experience. Experience has a tremendous impact on decision making. Autonomy, satisfaction, frustration, and feelings of uncertainty are some of the experiences in triage decision making. Nurses who have more years of experience as triage nurses will increase consistency in decision making. 
The same thing was stated by Dadashzadeh, Abdolahzadeh, Rahmani, and Ghojazadeh in 2013, that the more experience a nurse has, the more consistent in making decisions. Besides experience, intuition has an important role in triage decisions. Interventions according to decision-making chosen through intuition that is owned by nurses will make it more consistent in carrying out all their duties and responsibilities (Smith \& Cone, 2010).

\section{Conclusion}

Based on the results of this study, there was no significant difference used triage of four levels of modification of ATS and triage of five levels of ESI in accuracy and time triage. However, based on the distribution of data it can be concluded that the level of accuracy in the ESI triage results in a greater expected triage and a smaller under triage than a triage of four levels of ATS modification. Under triage causes long waiting times, unexpected risks, increases morbidity and mortality. The length of time required by the two triages were not exceed the standards time by the Ministry of Health ( $\leq 5$ minutes) (Departemen Kesehatan RI, 2011). ESI is easy to used because the flow is concise, clear, and structured as well as simple in making decisions in each indicator of existing categories. However, nurses at the Cibabat Hospital are sometimes confused in determining the amount of health workforce resources needed by patients.

Based on the results of the study stated that there is a tendency to use five levels of ESI triage. However, because the results obtained were not significantly different, the hospital could use a triage of four levels of ATS modification or a five-level triage of ESI. ESI Triage can be an alternative choice for using triage studies because it is applicatively easier to understand, faster, and accurate.

The results of this study can be used as further research related to the use of the five level ESI triage method in Emergency Services with several hospitals with the same criteria (multy center) so that more varied types of patient cases are obtained, nurse skills are more varied, and the number of patients is more many.

\section{References}

Ardiyani, V.M. (2015). Analisis peran perawat triage terhadap waiting time dan length of stay pada ruang triage di instalasi gawat darurat Rumah Sakit Dr. Saiful Anwar Malang. (Analysis of the role of triage nurses on waiting time and length of stay in the triage room in the emergency department of Dr Saiful Anwar Hospital, Malang). Care: Jurnal Ilmiah Ilmu Kesehatan, 3(1), 39-50. https://doi.org/10.33366/cr.v3i1.302

Bukhari, H., Albazli, K., Almaslmani, S., Attiah, A., Bukhary, E., Najjar, F., ..., \& AlMaghrabi, H. (2014). Analysis of waiting time in emergency department of Al-Noor Specialist Hospital, Makkah, Saudi Arabia. Open Journal of Emergency Medicine, 2(04), 67. https://doi.org/10.4236/ojem.2014.24012

Christ, M., Grossmann, F., Winter, D., Bingisser, R., \& Platz, E. (2010). Triage in der Notaufnahme. Dtsch Arztebl International, 107(50), 892-898. https://doi.org/892-898. 10.3238/arztebl.2010.0892

Considine, J., Ung, L., \& Thomas, S. (2001). Clinical decisions using the national triage scale: How important postgraduate education?. Accident and emergency nursing, 9, 101-108. https://doi.org/10.1054/ aaen.2000.0209

Dadashzadeh, A., Abdolahzadeh, F., Rahmani, A., \& Ghojazadeh, M. (2013). Factors affecting triage decision-making from the viewpoints of emergency department staff in Tabriz Hospitals. Iran Journal Critical Care Nurs, 6(4), 269-276.

Dahlan, M.S. (2013). Besar sampel dan cara pengambilan sampel dalam penelitian kedokteran dan kesehatan ( $3 r d$ ed). Salemba Medika.

Departemen Kesehatan RI. (2011). Standar pelayanan keperawatan gawat darurat di rumah sakit. (Standards for emergency nursing services in hospitals). Jakarta.

Ekins, K., \& Morphet, J. (2015). The accuracy and consistency of rural, remote and outpost 
Zustantria Agustin Minggawati: Comparison of Four-Level Modification Triage with Five Level ESI

triage nurse decision making in one Western Australia country health service region. Australasian Emergency Nursing Journal, 18(4), 227-233. https://doi.org/10.1016/j. aenj.2015.05.002

Elshove-Bolk, J., Mencl, F., van Rijswijck, B.T., Simons, M.P., \& van Vugt, A.B. (2007). Validation of the emergency severity index (ESI) in self-referred patients in a European emergency department. Emergency Medicine Journal, 24(3), 170-174. https://doi. org/10.1136/emj.2006.039883

FitzGerald, G., Jelinek, G.A., Scott, D., \& Gerdtz, M.F. (2009). Emergency department triage revisited. Emerg Med J., 27, 85-92. https://doi.org/10.1136/emj.2009.077081

Gilboy N., Tanabe T., Travers, D.A., \& Rosenau, A.M. (2011). Emergency severity index (ESI): A triage tool for emergency department care, version 4. Implementation handbook (2012 edition). AHRQ Publication No. 12-0014. Rockville, MD. Agency for Healthcare Research and Quality.

Golzari, S.E., Soleimanpour, H., Raoufi, P., Salarilak, S., Sabahi, M., Nouri, H., \& Heshmat, Y. (2014). Accuracy of emergency severity index, version 4 in emergency room patients' classification. Journal Analytic Respiratory Clinical Medic, 2(1), 39-44. https://doi.org/10.5681/jarcm.2014.006

Hinson, J.S., Martinez, D.A., Schmitz, P.S., Toerper, M., Radu, D., Scheulen, J., ..., \& Levin, S. (2018). Accuracy of emergency department triage using the emergency severity index and independent predictors of under-triage and over-triage in Brazil: A retrospective cohort analysis. International journal of emergency medicine, 11(1), 3. https://doi.org/10.1186/s12245-017-0161-8

Khankeh, H.R., Zavareh, D.K., Naghdloo, F.A., Hoseini, M.A., \& Rahgozar, M. (2007). Effect of triage on medical services waiting time and patient satisfaction in shahid rajae hospital emergency depart $\neg$ ment in Karaj Tehran: University of social welfare and rehabilitation. Iran Journal Nursing Midwifer., 18(1), 79-83.
Levsky, M.E., Young, S.E., Masullo, L.N., Miller, M.A., \& Herold T.J. (2008). The effect of an accelerated triage and treatment protocol on left witout being seen rates and wait times of urgetn patients at a military emergency departement. Military medicine, 173(10), 999-1003. https://doi.org/10.7205/ milmed.173.10.999

Mace, S.E., \& Mayer, T.A. (2013). Triage. The Practice Environment.

Nurmansyah, E., Susilaningsih, F.S., \& Setiawan. (2014). Tingkat ketergantungan dan lama perawatan pasien rawat observasi di IGD. (The level of dependence and length of stay of observational patients in the ED). Jurnal Keperawatan Padjadjaran, 2(3), 191201. https://doi.org/10.24198/jkp.v2i3.89

Ramdan, I.M., \& Rahman, A. (2017). Analisis resiko kesehatan dan keselamatan kerja pada perawat. (Health and safety risk analysis for nurses). Jurnal Keperawatan Padjadjaran, 5(3), 229-241. https://doi.org/10.24198/jkp. v5i3.645

RSUD Cibabat Cimahi. (2015). Laporan akuntabilitas kinerja pemerintah TA 2015 RSUD Cibabat Cimahi. (Government Performance Accountability Report FY 2015 Cibabat Cimahi Hospital). RSUD Cibabat Cimahi.

Safdar, A., Susilaningsih, F.S., \& Kurniawan, T. (2019). Relationship between workload performance and job satisfaction. Jurnal Keperawatan Padjadjaran, 7(3), 222-229. https://doi.org/10.24198/jkp.v7i3.1178

Smith, A., \& Cone, K.J. (2010). Triage decision making. Journal For Nurse in Staff Development, 26(1), E14-19. http://dx.doi. org/10.1097/NND.0b013e3181bec1e6

Villa, S., Weber, E.J., Polevoi, S., Fee, C., Maruoka, A., \& Quon, T. (2018). Decreasing triage time: Effects of implementing a stepwise ESI algorithm in an EHR. International Journal for Quality in Health Care, 30(5), 375-381. https://doi.org/10.1093/intqhe/ mzy056 